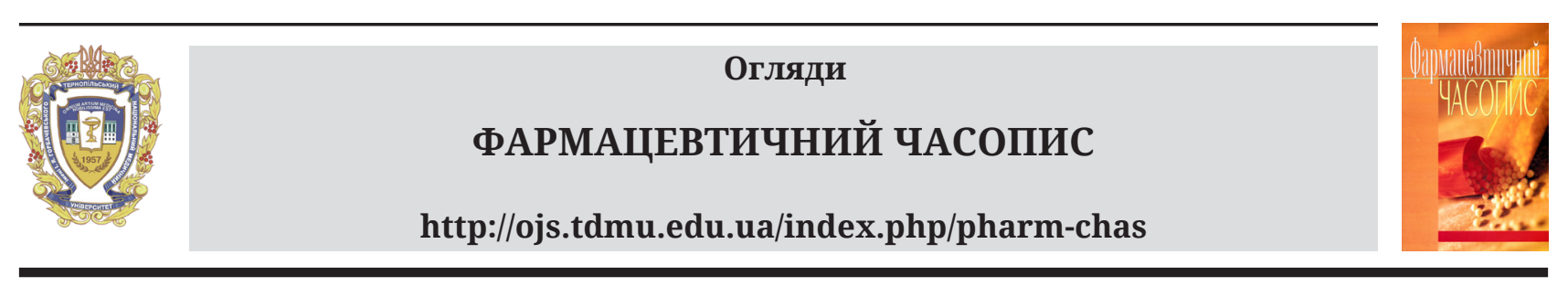

УДК 615.453.6

DOI https://doi.org/10.11603/2312-0967.2020.2.11204

\title{
ДИЗАЙН ЕКСПЕРИМЕНТУ ПРИ ПРОВЕДЕННІ ДОСЛІДЖЕНЬ ІЗ СТВОРЕННЯ ТАБЛЕТОВАНИХ ЛІКАРСЬКИХ ЗАСОБІВ
}

\author{
Т. А. Грошовий ${ }^{1}$, М. Б. Демчук ${ }^{1}$, Н. М. Белейㅁ, Ю. В. Найда², Б. В. Павлюк ${ }^{1}$ \\ Тернопільський національний медичний університет імені І. Я. Горбачевського МОЗ \\ України ${ }^{1}$ \\ ПАТ «Фармак», Київ \\ hrochovuy@tdmu.edu.ua
}

ІНФОРМАЦІЯ

Надійшла до редакції / Received: 24.05.2020

Після доопрацювання / Revised: 04.06.2020

Прийнято до друку / Accepted: 09.06.2020

\section{Ключові слова:}

дизайн експерименту;

дизайн якості;

математичне планування

експерименту;

таблетовані лікарські засоби;

якісні фактори;

дисперсійний аналіз.

\section{АНОТАЦІЯ}

Мета роботи. Аналіз і систематизація даних літератури щодо дизайну досліджень із використанням математичного планування експерименту при створенні та вдосконаленні технології таблетованих лікарських засобів. Матеріали і методи. В роботі використано методи інформаційного пошуку, аналізу даних літератури щодо дизайну експерименту на етапі вивчення якісних фракторів при проведенні досліджень зі створення таблетованих лікарських засобів.

Результати й обговорення. У роботі наведено дані літератури та власних досліджень щодо використання математичного планування експерименту при вивченні якісних фракторів на етапі розробки складу та технології таблеток. Наведено приклади використання планів латинських, греколатинських і гіпер-греко-латинських квадратів при вивченні якісних фракторів 3 однаковим числом рівнів. Для вивчення якісних фракторів із різним числом рівнів розглянуто приклади використання планів латинських кубів і паралелепіпедів.

Висновки. Дизайн якості $€$ важливим та широко використовуваним прийомом при розробці лікарських засобів. Його методи використовують експериментатори на різних етапах дослідження - від фрормування цілей до характеристики готового препарату. Особливо це важливо у процесі створення та дослідження таблеток, який $є$ багатостадійним. Застосування математичного планування експерименту на стадії планування досліджень дозволяє впровадити принцип «дизайн якості» як в наукових, так і в промислових умовах при створенні таблетованих лікарських засобів. Наведені приклади проведення досліджень із вивчення якісних фракторів 3 однаковим і різним числом рівнів, методи побудови планів дисперсійного аналізу, їхнього статистичного аналізу та інтерпретації результатів експериментальних досліджень.
Повідомлення 1. Дизайн експерименту при дослідженні впливу якісних факторів на етапі розробки таблетованих лікарських засобів
Вступ. Розробка складу та технології лікарських засобів (ЛЗ) здійснюється відповідно до настанови «Фармацевтична розробка (ICH Q8)» [1]. Дана настанова придатна для організації фрармацевтичної роз-

ISSN 2312-0967. Pharmaceutical review. 2020. № 2 
робки ЛП, підготовки модуля 3 «якість» реєстраційного досьє, для побудови систем управління якістю для фрармацевтичної промисловості, а також експертизи реєстраційних досьє, аудиту та інспектування на відповідність належній виробничій практиці. При розробці лікарської фрорми (ЛФ) представляють процес розробки складу і технології від початкової ідеї до остаточної композиції. При цьому мають бути обґрунтовані склад та межі вмісту допоміжних речовин (ДР), а також вибір раціональної технології.

При проведенні досліджень рекомендовано використовувати планування експерименту, що представляє структурований, організований метод визначення взаємозв'язку між фракторами, що впливають на процес, і якістю готової продукції. Для цього застосовують різні математико-статистичні методи, тому вживають термін математичне планування експерименту (МПЕ). Системний підхід до розробки, заснований на надійних наукових даних та управлінні ризиками для якості, який починається 3 попереднього визначення цілей і приділяє особливу увагу розумінню продукції та процесу, а також контролю процесу.

Дизайн якості (QbD) - це системний підхід до фармацевтичної розробки, і його прийоми використовують експериментатори від початку формування цілей дослідження до характеристики готового ЛЗ. Особливо це важливо при створенні та дослідженні таблетованих лікарських засобів (ТЛЗ), оскільки процес розробки оптимального складу та технології таблеток $€$ багатостадійним. Впровадження концепції QbD у розробку Лз забезпечує гарантію якості ліків для пацієнтів, зменшення ризиків на етапах виробництва, а також створює більшу впевненість регуляторних органів у сорері обігу ліків у надійній якості продукції при розгляді документації на затвердження.

Дизайн якості - це інтелектуальний підхід до підвищення якості ЛФ та процесу її виробництва. Цього можна досягти за допомогою раціонального планування експерименту, збору попередніх даних про досліджуваний об'єкт, включення всіх фракторів та контроль ЛФ $з$ врахуванням усіх фрармако-технологічних показників. Незважаючи на те, що концепція $\mathrm{QbD}$ базується на ризиках, вона дає результати, які мінімізують кількість досліджень для розробки оптимального складу та технології ЛФ. Принципи QbD закладені в нормативних документах із фрармацевтичної розробки (ICH Q8) [1], управління ризиками для якості (ICH Q9) [2] та фрармацевтичної системи якості (ICH Q10) [3].

B основі QbD у більшості випадків лежить MПE. На початку XX століття Рональд Фішер ввів концепцію застосування статистичного аналізу на етапі планування досліджень, а не в кінці експерименту [4].

Застосування МПЕ на стадії планування досліджень дозволяє впровадити принцип «дизайн якості» як в наукових, так і в промислових умовах, засто- совуючи глибокий підхід до знань, що включає системне мислення, розуміння варіацій, теорію пізнання та психологію. При використанні МПЕ широко використовують досягнення інорормаційних технологій.

Науковцями України набутий певний дослід із використання МПЕ при створенні та дослідженні ЛЗ. Так, в монографії [5] наведені результати авторів з використання МПЕ при проведенні наукових досліджень у фрармації. На багатьох прикладах наведені схеми проведення досліджень 3 отримання витяжок 3 лікарської рослинної сировини, вибору ДР, які найбільш придатні для створення ЛФ, вивчення впливу кількісних фрармацевтичних фракторів на основні властивості Л3. Описані основні принципи вибору фракторів за допомогою апріорного ранжування, експериментальної оцінки фракторів за допомогою методу випадкового балансу, методи побудови планів дисперсійного аналізу, їх статистичного аналізу та інтерпретації результатів експериментальних досліджень. Розглянуто пошук оптимального складу і технології лз за допомогою методів регресійного аналізу.

Проведено огляд літературних джерел та наведено результати власних досліджень із використання МПЕ при створенні ЛЗ [6]. При цьому наведено алгоритм дії експериментатора при вивчені якісних і кількісних фрармацевтичних фракторів у процесі створення та вдосконалення технології ЛЗ.

Мета роботи - аналіз і систематизація даних літератури щодо дизайну досліджень 3 використанням математичного планування експерименту при створенні та вдосконаленні технології Тлз.

Матеріали і методи. У роботі використано методи інорормаційного пошуку, аналізу даних літератури щодо дизайну експерименту на етапі вивчення якісних фракторів при проведенні досліджень із створення ТЛЗ.

Результати й обговорення. Значну частку асортименту Л3, що зареєстровані на фрармацевтичному ринку України, складають таблетовані ЛФ (49,09 \% асортименту) [7]. Процес створення ТЛЗ багатостадійний. Кількість технологічних стадій залежить від фрізико-хімічних і технологічних властивостей активних фрармацевтичних інгредієнтів (АФІ), їх дози в таблетках та вибраної технології. Так, серед зареєстрованих ТЛЗ в Україні найбільшу кількість становлять таблетки, вкриті оболонкою (2348 найменувань) та таблетки без оболонки (2252 найменувань), а також таблетки 3 модифрікованим вивільненням (194 найменувань), таблетки для жування (94 найменування), таблетки, що диспергуються (71 найменувань) та інші [7]. Кожен вид таблеток вимагає специфрічного дизайну в процесі проведення експериментальних досліджень. Так, при створенні таблеток прямим пресування без оболонки вивчають тип наповнювача (розпушувача), ковзких і змащуючих речовин. При отриманні таблеток із використанням вологої грануляції додатково вивчають вплив

ISSN 2312-0967. Фармацевтичний часопис. 2020. № 2 
зв'язуючої речовини, режимів сушки гранул та ін. При створенні таблеток з оболонкою вивчають тип плівкоутворюючої системи, природи барвників, пігментів, пластисрікаторів. Залежно від методу нанесення оболонки й обладнання вивчають температуру повітря, товщину оболонки та ін.

Математичні методи використовують як при створенні плану експерименту, так і на стадії обробки спостережень. План експерименту повинен надавати можливість скорочення загального числа дослідів, але при цьому забезпечувати отримання достовірних результатів. Такого компромісу не можна досягти за допомогою суб'єктивних підходів або примітивних емпіричних способів.

Особливо відповідальним є етап МПЕ, коли вивчається вплив якісних факторів, які при створенні ТЛЗ відрізняються різноманітністю та широким асортиментом.

При плануванні експерименту з якісними фракторами використовують плани дисперсійного аналізу. Статистично обґрунтований план визначає і метод математичного аналізу результатів, тому сучасний експеримент неможливо вірно спланувати, не знаючи основ дисперсійного аналізу [6].

Дисперсійний аналіз - це статистичний метод, за допомогою якого проводять розподіл загальної суми квадратів спостережень на складові, зумовлені впливом різних фракторів, їх взаємодії і випадкових змінних. Головне призначення дисперсійного аналізу статистично виявити вплив різних фракторів на мінливість ознаки, що вивчається. Дисперсійний аналіз часто використовується для технологічних експериментів [5].

При проведенні досліджень із вивчення якісних фракторів при створенні таблеток використовують однофракторний та багатофракторний дисперсійний аналіз. При побудові матриць експерименту використовують латинські, греко-латинські та гіпер-греко-латинські квадрати. При цьому вивчається від 1 до 10ти фракторів. Вибір плану експерименту залежить від завдань досліджень, кількості ДР, які вивчаються, фрізико-хімічних властивостей АФІ та дози в ЛФ.

Перевагою МПЕ $€$ не тільки скорочення числа дослідів, але й отримання інорормації про взаємодію між рівнями фракторів, що при традиційному експерименті отримати неможливо [5].

При розробці складу таблеток кріоліофрілізованої ксенодерми з ліпідами використовували двофакторний збалансований план експерименту [8].

При проведенні 3-сракторних порівняльних експериментів найбільш використовуваними є симетричні ортогональні плани, основані на латинських квадратах. При проведенні досліджень із використання латинських квадратів число рівнів для кожного із фракторів може складати від 3 до 10. Дисперсійний аналіз експериментальних даних дозволяє оцінити статистичну значущість вивчених фракторів, а при наявності повторних дослідів перевірити гіпотезу про взаємодію між фракторами [5].

Матрицю експерименту на основі 3х3 латинського квадрату використовували при проведенні досліджень із розробки складу і технології таблеток торсеміду методом прямого пресування. Вивчався вплив наповнювачів, ковзних та змащувальних речовин, розпушувачів на фрармако-технологічні властивості мас для таблетування та готових таблеток [9]. Подібні дослідження виконані при фрармацевтичній розробці таблеток бісопрололу методом прямого пресування [9].

При розробці складу матриксних таблеток із сухим екстрактом листя чорниці вивчали вплив природи зв'язуючої речовини, вологовмісту та фрракційного складу на фрармако-технологічні показники гранульованих мас для таблетування та матриксних таблеток [10].

Вивчали вплив 9 ДР на фрармако-технологічні характеристики шипучих таблеток ацетилсаліцилової кислоти, парацетамолу та аскорбінової кислоти [11]. Однозначними лідерами за впливом на більшість досліджених фармако-технологічних показників виявилася лактоза безводна (SuperTab® 22AN), кросповідон XL-10, натрію стеарилсумарат (Pruv®). Результати є підґрунтям для розробки оптимального складу шипучих таблеток.

Схожий дизайн досліджень використали при виборі кращих ДР при створенні плаваючих таблеток цитрату мозаприду [12] і комбінованого лікарського засобу у формі шипучих таблеток під умовною назвою «Комбітусин» [13].

У тих випадках, коли вивчають 4 групи якісних фракторів, взятих на рівному числі рівнів, використовують греко-латинський квадрат. При цьому до трьох досліджуваних фракторів по латинському квадрату, не збільшуючи загального числа дослідів, додається четвертий фрактор. В експерименті можна вивчати 3×3, 4x4, 5×5, 7x7, 8x8 греко-латинські квадрати. Не існують ортогональні $6 \times 6$ квадрати. При використанні 4х4 греко-латинського квадрату можна вивчити 16 ДР, при цьому кількість реалізованих дослідів буде 16. Для отримання інорормації про взаємодію між рівнями фракторів рекомендується реалізувати повторні досліди, тобто загальна кількість буде складати 32 досліди, що збільшить чутливість аналізу [5].

Греко-латинський квадрат 4×4 використовували при проведенні досліджень із розробки оптимального складу таблеток на основі стандартизованих сухих екстрактів мальви лісової і подорожника ланцетолистого [14]. Було вивчено 16 ДР, які були згруповані в чотири основні групи (фактори): наповнювачі, розпушувачі, зв'язуючі речовини та регулятори вологи. У тих випадках, коли експериментальне значення критерію Фішера було більшим від табличного, робили висновки про значущість вивченого фрактора. Для значущих фракторів будували діаграми та ранжовані

ISSN 2312-0967. Pharmaceutical review. 2020. № 2 
ряди переваг, в яких якісні фрактори розміщували у послідовності, що залежала від величини їх впливу на вивчений показник.

3 використанням 4x4 греко-латинського квадрату проведені дослідження 3 розробки складу та технології таблеток на основі екстракту плодів каштану кінського сухого «Ескувіт». Оптимальний склад таблеток отримали при використанні: цукру молочного (гранулак-70), магнію карбонату основного, крохмалю картопляного і натрію кроскармельози [15]. При розробці таблеток на основі густого екстракту кореневищ із коренями валеріани, плодів глоду, трави звіробою, листя м'яти перцевої та шишок хмелю за допомогою МПЕ вивчено вплив чотирьох основних груп ДР на фрармако-технологічні властивості таблеток «Седавіт» і обрано кращі ДР для подальших досліджень [15].

Науково обґрунтовано склад і технологію оригінального лікарського засобу «Ангіолін» в таблетках, який має кардіо- та нейропротекторну дії [16]. Таблетки отримували методом вологої грануляції. Для вивчення чотирьох груп якісних факторів використовували 4х4 греко-латинський квадрат. У результаті дослідження обрано оптимальні ДР, які забезпечували отримання таблеток 3 фрармако-технологічними показниками, що відповідають діючим вимогам ДФУ.

У результаті проведених фрізико-хімічних, фрармако-технологічних та морфометричних досліджень субстанцій L-триптофрану та тіотриазоліну, спрогнозовано, а надалі й підтверджено можливість отримання таблеток на їх основі методом вологої грануляції. Для цього вивчали чотири групи ДР: наповнювачі, розпушувачі, зв'язуючі розчини і солюбілізатори [17].

План експерименту на основі 4х4 греко-латинського квадрату використовували при створенні та стандартизації нового протиепілептичного препарату 3 вираженими антидепресивними, ноотропними, нейропротекторними та антиоксидантними властивостями на основі фріксованої комбінації карбамазепіну з тіотриазоліном [18].

Схожі плани експерименту використовували при розробці складу і технології таблеток, що містять цинку аспарагінат, кислоту аскорбінову та сухий екстракт ехінацеї пурпурової [19], при розробці складу та технології таблеток-ядер екстракту цикорію та кукурудзи [20], в дизайні експерименту таблеток екстракту кори осики та комбінованих таблеток, що містять екстракт кори осики та вісмуту субцитрат під умовною назвою «Віспулін» [21], при розробці таблеток амлодипіну бесилату та валсартану методом сухої грануляції (компактування) [22], при створенні таблеток сухого порошку біомаси Flammulina velutipes [23], таблеток L-аргініну з тіотриазоліном [24], таблеток «Амізон» [9].

Для розробки оптимального складу і технології таблеток на основі стандартизованого сухого складного екстракту кардіотонічної дії «Кардіостен» дослі- джено 4 групи ДР (наповнювачі, розпушувачі, регулятори вологи, зв'язуючі речовини) та їх вплив на властивості мас для таблетування і фрармако-технологічні показники таблеток [25].

У кожному випадку при вивченні 4-х фракторів дослідники підбирали ДР, які найкраще впливали на фрармако-технологічні властивості таблеток. Вибір конкретних ДР визначали за технологічними властивостями АФІ, дозою в ЛФ та досвідом експериментатора.

При створенні ТЛЗ часто виникає необхідність вивчити 5 груп ДР. Обґрунтування доцільності збільшення кількості ДР приймається залежно від завдань досліджень. При вивченні 5 факторів, кожний з яких взятий на 5 рівнях, необхідно реалізувати 3125 дослідів. Для зменшення кількості дослідів використовують один із планів дисперсійного аналізу - дробний план $1 / 5^{5}$, що дасть можливість скоротити число дослідів в 125 разів. При використанні такого плану завжди необхідно реалізовувати повторні досліди, оскільки число ступенів свободи для помилки дорівнює нулю. В таких випадках використовують п'ятифракторний експеримент на основі $5 \times 5$ гіпер-греко-латинського квадрату [5].

План експерименту на основі $5 \times 5$ греко-латинського квадрату використали при проведенні досліджень з розробки оптимального складу таблеток для жування на основі лецитину і кальцію цитрату під умовною назвою «Кальцитин» [26], таблеток магнію аспарагінату, вкритих кишковорозчинною оболонкою [27], таблеток, що містить магнію аспарагінат та вітамін $B_{6}$ [27], таблеток фрамотидину з тіотриазоліном [28], таблеток екстракту листя тополі китайської [29], таблеток цинку аспарагінату, покритих кишковорозчинною оболонкою [19], таблеток «Кардіотрил» [30], таблеток кислоти ацетилсаліцилової, які отримували методом прямого пресування [31], таблеток валоцикловіру [9].

При створенні таблеток виникають ситуації, коли необхідно вивчити 6 якісних фракторів. В таких випадках рекомендується використовувати шестифакторний план на основі 5х5 латинського квадрату четвертого порядку. За допомогою вказаного плану можна вивчити 30 ДР, потрібно реалізувати 25 серій дослідів у двох повторностях [5].

За допомогою шестифракторного експерименту на основі гіпер-греко- латинського квадрату четвертого порядку проведені дослідження 3 розробки оптимального складу таблеток на основі стандартизованих сухих екстрактів листя чорниці та трави козлятника в комбінації з таурином [32], розробці оптимального складу та технології фрармакологічного засобу седативної дії з екстрактами валеріани, меліси та гліцину [33].

Досліджено вплив 6 груп ДР на технологічні характеристики таблеток «Гіпертрил» та підтверджено можливість їх отримання методом прямого пресуван-

ISSN 2312-0967. Фармацевтичний часопис. 2020. № 2 
ня. Проведені дослідження дозволили виявити «лідерів»: МКЦ 102, Prosolv 90, маніт, натрію кроскармелоза, кальцію дигідрофросфрат безводний, неусілін УС 2, кальцію стеарат за їх впливом на різні технологічні показники таблеток гіпертрилу [34].

При проведенні досліджень зі створення таблеток виникають ситуації, коли кількість ДР в одній технологічній групі $€$ різною, наприклад, з групи розпушувачів можна підібрати 6 і більше ДР, а з групи змащуючих - 3-5 ДР.

У таких випадах застосовують частотні квадрати, прямокутники і куби. При використанні частотних квадратів два фрактори можна вивчати з однаковим числом рівнів, а третій - 3 іншим числом рівнів. При використанні частотних прямокутників один фрактор вивчається на трьох рівнях, другий фактор - на чотирьох рівнях, а третій фрактор - на восьми рівнях. При цьому необхідно реалізувати 24 серії дослідів. При використанні частотних прямокутників два фрактори вивчаються на однаковому числі рівнів (наприклад на 4-х), а інші два фрактори на іншому числі рівнів (наприклад на 5-х).

Латинські куби використовують для побудови чотирифракторних дробних планів. При цьому число дослідів буде складати 27 замість 81 для повного факторного експерименту. При проведенні досліджень використовують латинські гіперкуби першого порядку, латинські куби другого порядку, греко-латинські куби другого порядку, латинські гіперкуби третього порядку. Так, при використанні греко-латинського кубу другого порядку 3 якісних фрактори вивчаються на 3-х рівнях, а інші два фрактори - на 9 рівнях. При використанні латинських кубів третього порядку чотири фрактори вивчаються на 3-рівнях, а ще один фрактор - на 27 рівнях.

За допомогою греко-латинського кубу 2-го порядку вивчено вплив 27 ДР на фрармако-технологічні показники таблеток, на основі екстракту листя грушанки [35]. ДР були згруповані в п'ять груп: наповнювачі на основі неорганічних солей (3 рівні), змащувальні речовини (3 рівні), розпушувачі (3 рівні), наповнювачі на основі МКЦ та її комбінацій (9 рівнів) і наповнювачі на основі цукрів (9 рівнів). П'ятифакторний план експерименту використовували при дослідженні порошкових мас і таблеток на основі кріоліофілізованої ксенодерми свині [8].

При створені таблеток «Індотрилу» 3 фрактори вивчалися на 3 рівнях і один - на 9 рівнях [30]. План експерименту на основі гіпер греко-латинського паралелепіпеда використовували при розробці складу таблеток декскетопрофрену трометамолу [36]. При вдосконаленні складу та технології таблеток «Антраль» для вивчення 4 фракторів використовували несиметричний дробний план на основі латинського паралелепіпеда першого порядку [9].

При створенні таблеток їх контролюють за багатьма фрармако-технологічними показниками. На підставі дисперсійного аналізу експериментальних даних роблять висновки про статистичну значущість вивчених фракторів на фрармако-технологічні властивості порошкових мас для таблетування і готових таблеток (відгуки). За кожним параметром, використовуючи критерій Дункана, будують ранжовані ряди переваг [5].

При дослідженні багатьох відгуків таблеток перед експериментатором стоїть завдання вибору кращих ДР. Виникають ситуації, коли одна із вивчених ДР найкраще сприяє прискоренню часу розпадання, однак дає найгірший результат стійкості таблеток до роздавлювання. Для вибору кращих поєднань ДР в складі таблеток використовують функцію бажаності або функцію корисності [6].

Висновки. Проведений аналіз літературних джерел показав, що МПЕ, в основі яких лежить дисперсійний аналіз експериментальних даних використовується багатьма дослідниками при створенні ТЛЗ.

Останніми роками 3'явились нові напрямки дизайну експерименту при проведенні наукових досліджень. Запропонована велика кількість комп'ютерних програм, які дозволяють оптимізувати експериментальні дослідження та виробничий процес, враховують сучасні досягнення статистики, а також призначені для побудови та інтерпретації результатів отриманих експериментальних даних.

Конфлікт інтересів: відсутній.

Conflict of interest: authors have no conflict of interest to declare.

\title{
EXPERIMENTAL DESIGN IN RESEARCH AT THE CREATION OF TABLET MEDICINES
}

\author{
T. A. Hroshovyi ${ }^{1}$, M. B. Demchuk ${ }^{1}$, N. M. Beley ${ }^{1}$, Yu. V. Naida², B. V. Pavlyuk ${ }^{1}$ \\ I. Horbachevsky Ternopil National Medical University ${ }^{1}$ \\ PJSC "Farmak", Kyiv² \\ hrochovuy@tdmu.edu.ua
}

The aim of the work. Analysis and systematization of literature data on research design using mathematical experiment planning when creating and improving the technology of tablet preparations.

Materials and Methods. The methods of information retrieval, analysis of literature data on the design of the experiment at the stage of studying qualitative factors during research on the creation of tablet medicines were used in the work.

ISSN 2312-0967. Pharmaceutical review. 2020. № 2 
Results and Discussion. The literature data and our own research on the use of mathematical experiment planning in the study of qualitative factors at the stage of development of the composition and technology of tablet medicines are presented in the work. Examples of using plans of Latin, Greek-Latin and hyper-Greek-Latin squares for the study of qualitative factors with the same number of levels are given. Examples of using plans of Latin cubes and parallelepipeds to study qualitative factors with a different number of levels are considered.

Conclusions. Quality design is an important and widely used technique in pharmaceutical development. Experimenters use its methods at different stages of the study - from setting goals to characterizing the finished product. This is especially important in the process of creating and researching tablet medicines, which is multistage. The use of mathematical experiment planning at the research planning stage allows you introduce the principle of "quality design" in both scientific and industrial conditions when creating tablet medicines. The examples of conducting research on the study of qualitative factors with the same and different number of levels, methods for constructing plan of dispersion analysis, their statistical analysis and interpretation of the results of experimental studies were presented.

Key words: experimental design; quality design; mathematical experiment planning: tablet medicines; quality factors; dispersion analysis.

\title{
ДИЗАЙН ЭКСПЕРИМЕНТА ПРИ ПРОВЕДЕНИИ ИССЛЕДОВАНИЙ С СОЗДАНИЯ ТАБЛЕТИРОВАННЫХ ЛЕКАРСТВЕННЫХ СРЕДСТВ
}

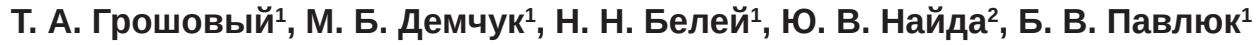 \\ Тернопольский национальный медицинский университет имени И. Я. Горбачевского МОз Украины ${ }^{1}$ \\ чАО «Фармак», Киев ${ }^{2}$ \\ hrochovuy@tdmu.edu.ua
}

Цель работы. Анализ и систематизация данных литературы по дизайну исследований с использованием математического планирования эксперимента при создании и совершенствовании технологии таблетированных лекарственных средств.

Материалы и методы. В работе использованы методы иноормационного поиска, анализа данных литературы по дизайну эксперимента на этапе изучения качественных фракторов при проведении исследований по созданию таблетированных лекарственных средств.

Результаты и обсуждение. В работе представлены данные литературы и собственных исследований по использованию математического планирования эксперимента при изучении качественных фракторов на этапе разработки состава и технологии таблеток. Приведены примеры использования планов латинских, греко-латинских и гипер-греко-латинских квадратов при изучении качественных фракторов с одинаковым числом уровней. Для изучения качественных факторов с различным числом уровней рассмотрены примеры использования планов латинских кубов и параллелепипедов.

Выводы. Дизайн качества является важным и широко используемым приемом при разработке лекарственных средств. Его методы используют экспериментаторы на разных этапах исследования - от фрормирования целей к характеристике готового препарата. Особенно это важно в процессе создания и исследования таблеток, который является многостадийным. Применение математического планирования эксперимента на стадии планирования исследований позволяет внедрить принцип «дизайн качества» как в научных, так и в промышленных условиях при создании таблетированных лекарственных средств. Приведенные примеры проведения исследований по изучению качественных фракторов с одинаковым и разным числом уровней, методы построения планов дисперсионного анализа, их статистического анализа и интерпретации результатов экспериментальных исследований.

Ключевые слова: дизайн эксперимента; дизайн качества; математическое планирование эксперимента; таблетированные лекарственные средства; качественные фракторы; дисперсионный анализ.

\section{Список бібліографрічних посилань}

1. СТ-Н 42-3.0:2011. Настанова. Лікарські засоби. Фармацевтична розробка (ICH Q8). Вид. офріц. Київ, МОЗ України, 2011. 42 с.

2. СТ-Н 42-4.2:2011. Лікарські засоби. Управління ризиками для якості (ICH Q9). Вид. офріц. Київ, МO3
України, 2011. 30 с

3. СТ-Н 42-4.3:2011. Лікарські засоби. Фармацевтична система якості (ICH Q10). Вид. офріц. Київ, МO3 України, 2011. 30 с

4. Фишер Р. Статистические методы для

ISSN 2312-0967. Фармацевтичний часопис. 2020. № 2 
исследователей : пер. с анг. Москва : Госстатиздат, 1958. 268c

5. Математичне планування експерименту при проведенні наукових досліджень в фрармації / Грошовий Т. А. [та ін.]. Тернопіль : ТДМУ. Укрмедкнига, 2008. 368 с.

6. Оптимізація технологічних процесів створення лікарських засобів за допомогою математичного планування експерименту / Грошовий Т. А. [та ін.] Фармацевтичний часопис. 2007. № 1. С. 21-28.

7. Гуреєва С. М., Грошовий Т. А., Лукашів О. І. Дослідження асортименту допоміжних речовин, які використовують у лікарських засобах, що зареєстровані на території України. Повідомлення 1. Дослідження асортименту лікарських фрорм та допоміжних речовин, які використовують у виробництві таблеток (без оболонки). Фармацевтичний часопис. 2012. № 4 (24). С. 178183.

8. Равлів Ю. А. Розробка технології та дослідження лікарських засобів на основі кріолісрілізованої ксенодерми : авторефр. дис.... к-та фрармац. наук : 15.00.01. Львів, 2015. 24 с.

9. Гуреєва С. М. Теоретичне та експериментальне обґрунтування розробки твердих лікарських форм 3 діючими речовинами 3 урахуванням біосрармацевтичної системи класифрікації : автореф. дис.... д-ра фрармац. наук : 15.00.00. Львів, 2016. 46 с.

10. Рубан О. А., Колісник Т. Є., Сліпченко Г. Д. Застосування методу математичного планування експерименту при оптимізації складу та технології матриксних таблеток із сухим екстрактом листя чорниці. Фармацевтичний часопис. 2018. № 2. C. 41-47.

11. Тригубчак О. В., Грошовий Т. А., Гуреєва С. М. Дослідження впливу природи допоміжних речовин на показники якості шипучих таблеток ацетилсаліцилової кислоти, парацетамолу та аскорбінової кислоти. Актуальні питання срармацевтичної і медичної науки та практики. 2018. T.11, № 1(26). C. 64-68.

12. Sunil Kumar Shah, Neeraj Kumar, Neelesh Choubey et al. Formulation and optimization of expandable gastro retentive floating matrix tablet of Mosapridecitrate using factorial design. International Journal of Pharmacy and Pharmaceutical research. 2018. Vol. 12(1). P. 7796.

13. Басакіна І. І. Розробка складу та технології шипучих таблеток комплексної дії для лікування захворювань органів дихання : авторефр. дис.... к-та фрармац. наук : 15.00.01. Харків, 2011. 25 с.

14. Белей С. Я. Розробка складу, технології та дослідження таблеток на основі екстрактів мальви лісової і подорожника ланцетолистого : автореср. дис.... к-та фрармац. наук : 15.00.01. Львів, 2019. $24 \mathrm{C}$.

15. Шалата В. Я. Розробка технології та дослідження таблеток з рослинними екстрактами венотонізуючої та седативної дії : авторефр. дис. ... канд. фрармац. наук : 15.00.01. Львів, 2013. 24 с.
16. Бідненко О. С. Розробка і стандартизація таблеток «Ангіолін» : автореф. дис. ... к-та фрармац. наук : 15.00.03. Харків, 2013. 24 с.

17. Борсук С. О. Розробка технології та стандартизація нового комбінованого лікарського засобу 3 триптофраном та тіотриазоліном : авторефр. дис.... к-та фрармац. наук : 15.00.03. Харків, 2013. 24 с.

18. Німенко Г. Р. Розробка і стандартизація таблеток на основі карбамазепіну з тіотриазоліном : автореф. дис....к-та фрармац. наук : 15.00.03. Харків, 2018. $24 \mathrm{c}$.

19. Коваль В. М. Розробка складу, технології і стандартизація таблеток, що містять цинку аспарагінат, кислоту аскорбінову та екстракт ехінацеї : авторефр. дис.... к-та фрармац. наук : 15.00.00. Львів, 2012. 22 с.

20. Єзерська О. І. Обгрунтування складу, технології та дослідження таблеток з екстрактом цикорію і кукурудзи : авторефр. дис.... к-та фрармац. наук : 15.00.01. Львів, 2014. 23 с.

21. Онишків О. І. Розробка складу та технології таблеток на основі фрітоекстракту кори осики : авторефр. дис.... к-та фрармац. наук : 15.00.01. Львів, 2013. 20 с.

22. Юр'єва О. О. Розробка складу та технології комбінованого таблетованого лікарського засобу антигіпертензивної дії : авторефр. дис.... к-та фрармац. наук : 15.00.01. Львів, 2019. 24 с.

23. Буткевич Т. А., Сятиня М. Л., Попович В. П. Вивчення впливу допоміжних речовин на фрармакотехнологічні властивості таблеток сухого порошку біомаси Flammulina velutipes. Фармацевтичний часопис. 2017. № 3. С. 47-51.

24. Хромильова О. В. Вивчення впливу допоміжних речовин на фрармако-технологічні характеристики таблеток І-аргініну 3 тіотриазоліном. Фармацевтичний часопис. 2018. № 4. С. 35-41.

25. Кухтенко О. С. Методологічні, технологічні, біофармацевтичні аспекти розробки складних екстрактів та лікарських засобів на їх основі : авторефр. дис. ...д-ра срармац. наук : 15.00.01. Запоріжжя, 2019. 50 с.

26. Белей Н. М. Розробка складу, технології і дослідження кальцій- та лецитинвміщуючих таблетованих лікарських препаратів : автореф. дис.... к-та фрармац. наук : 15.00.01. Львів, 2009. 22 с.

27. Васенда М. М. Розробка складу і технології таблеток на основі магнію аспарагінату : автореф. дис.... к-та фрармац. наук : 15.00.01. Львів, 2010. 20 с.

28. Демчук М. Б. Розробка складу, технології i дослідження таблеток фрамотидину з тіотриазоліном : авторефр. дис.... к-та фрармац. наук : 15.00.01. Львів, 2011. 22 c.

29. Денис А. І. Розробка складу, технології та дослідження таблеток на основі екстракту листя тополі китайської : автореф. дис.... к-та фрармац. наук : 15.00.01. Львів, 2012. 20 с.

30. Кучеренко Л. І. Розробка технології і стандартизації таблетованих лікарських препаратів на основі похідних1,2,4-триазолів : автореф. дис. ... д-ра фрармац. наук : 15.00.03. Харків, 2010. 44 с.

ISSN 2312-0967. Pharmaceutical review. 2020. № 2 
31. Тригубчак О. В. Розробка складів і технологій таблеток, що містять кислоту ацетилсаліцилову, та ії поєднання з тіотриазоліном : автореф. дис.... к-та фармац. наук : 15.00.01. Львів, 2010. 20 с.

32. Барчук О. 3. Розробка складу, технології та методів стандартизації таблеток на основі срітоекстрактів чорниці звичайної та козлятника лікарського : автореф. дис.... к-та фрармац. наук : 15.00.01. Львів, 2018. 24 с.

33. Логойда Л. С. Розробка і стандартизація седативного фармакологічного засобу з екстрактами валеріани, меліси та гліцину в таблетках : авторефр. дис. ... к-та фрармац. наук : 15.00.03. Харків, 2013. 24 с.

\section{References}

1. Guidance. Pharmaceutical development (ICH Q8). [Настанова СТ-Н 42-3.0:2011. Лікарські засоби. Фармацевтична розробка (ICH Q8)] Kyiv; 2011. Ukrainian.

2. Guidance. Quality risk management ( $\mathrm{ICH}$ Q9). [Настанова СТ-Н 42-4.2:2011. Лікарські засоби. Управління ризиками для якості (ICH Q9)] Kyiv; 2011. Ukrainian.

3. Guidance. Pharmaceutical quality system ( $\mathrm{ICH} \mathrm{Q} 10)$. [Настанова СТ-H 42-4.3:2011. Лікарські засоби. Фармацевтична система якості (ICH Q10)] Kyiv; 2011. Ukrainian.

4. Fisher R. Statistical methods for researchers. [Статистические методы для исследователей] Moscow: Gosstatizdat; 1958. Russian.

5. Hroshovyi TA, Martsenyuk VP, Kucherenko LI, Vronska LV, Huryeyeva CM. Mathematical planning of experiment in pharmacy. [Математичне планування експерименту при проведенні наукових досліджень в формації] Ternopil: Ternopil State Medical University; 2008. Ukrainian.

6. Hroshovyi TA, Beley NM, Kucherenko LI, Vasenda MM, Markiv NV, Tryhubchak OV, et al. [Optimization of technological processes of drugs creation by means of mathematical planning of experiment]. Farmatsevt chasop. 2007;1: 21-8. Ukrainian.

7. Huryeyeva CM, Hroshovyi TA, Lukashiv OI. [Research of the assortment of excipients used in medicines products, which are registered in Ukraine]. Farmatsevt chasop. 2012;4(24): 178-83. Ukrainian.

8. Ravliv YuA. Development of the technology and research of drugs which are based on the cryolyophilized xenoderm. Extended abstract of Candidate's thesis. Lviv: Danylo Halytsky Lviv National Medical University; 2015. Ukrainian.

9. Gureyeva SM. The theoretical and experimental substantiationof technology of solid dosage forms based on Biopharmaceutics Classification System of Active Pharmaceutical Ingredients. Extended abstract of Doctor's thesis. Lviv: Danylo Halytsky Lviv National Medical University; 2016. Ukrainian.

10. Ruban OA, Kolisnyk TYe, Slipchenko GD. [Application of experimental design method in optimization of composition and technology for matrix tablets containing Vaccinium Myrtillus leaf dry extract]. Farma-
34. Парнюк Н. В. Розробка технології і стандартизації таблеток «Гіпертрил» : авторефр. дис.... к-та фрармац. наук : 15.00.03. Харків, 2016. 26 с.

35. Дарзулі Н. П. Розробка складу, технології та дослідження таблетованих лікарських засобів на основі екстракту грушанки круглолистої : автореср. дис.... к-та фрармац. наук : 15.00.01. Львів, 2019. 24 с.

36. Шошміна О. В., Гуреєва С. М., Вронська Л. В. Вивчення впливу допоміжних речовин на фрармакотехнологічні властивості таблеток-ядер декскетопрофену. Фармацевтичний журнал. 2019. № 1. С. 53-63.

tsevt chasop. 2018;2: 41-7. DOI: 10.11603/23120967.2018.2.9003. Ukrainian.

11. Tryhubchak OV, Hroshovy TA, Huryeyeva CM. [Investigation of excipients' nature influence on the quality indices of effervescent tablets of acetylsalicylic acid, paracetamol and ascorbic acid]. Aktualni pytannia farmatsevtychnoi i medychnoi nauky ta praktyky. 2018;1(26): 64-8. DOI: 10.14739/24092932.2018.1.123712. Ukrainian.

12. Sunil Kumar Shah, Neeraj Kumar, Neelesh Choubey et al. Formulation and optimization of expandable gastro retentive floating matrix tablet of Mosapridecitrate using factorial design. International Journal of Pharmacy and Pharmaceutical Research. 2018;12(1): 77-96.

13. Basakina II. Development of composition and technology of effervescent tablets of complex action for the treatment of respiratory diseases. Extended abstract of Candidate's thesis. Kharkiv: National University of Pharmacy; 2011. Ukrainian.

14. Beley SYa. Development of the composition, technology and investigation of the tablets based on malva sylvestris and plantago lanceolata extracts. Extended abstract of Candidate's thesis. Lviv: Danylo Halytsky Lviv National Medical University; 2019. Ukrainian.

15. Shalata VYa. Development of the technology and investigation of the tablets with plant extracts of venotonic and sedative actions. Extended abstract of Candidate's thesis. Lviv: Danylo Halytsky Lviv National Medical University; 2013. Ukrainian.

16. Bidnenko OS. Development and standardization of Angiolin tablets. Extended abstract of Candidate's thesis. Kharkiv: National Pharmaceutical University; 2013. Ukrainian.

17. Borsuk SO. Technology development and standardization of the new tryptophan and thiotriazoline combined drug. Extended abstract of Candidate's thesis. Lviv: Danylo Halytsky Lviv National Medical University; 2013. Ukrainian.

18. Nymenko GR. Development and standardization of carbamazepine-based tablets with thiotriazolin. Extended abstract of Candidate's thesis. Kharkiv: National Pharmaceutical University; 2018. Ukrainian.

19. Koval VM. Development of the composition, technology and standardization of the tablets with zinc aspar-

ISSN 2312-0967. Фармацевтичний часопис. 2020. № 2 
tate, ascorbic acid and Echinacea extract. Extended abstract of Candidate's thesis. Lviv: Danylo Halytsky Lviv National Medical University; 2012. Ukrainian.

20. Yezerska OI. Development of the composition, technology and research of tablets with chicory and corn extract. Extended abstract of Candidate's thesis. Lviv: Danylo Halytsky Lviv National Medical University; 2014. Ukrainian.

21. Onyshkiv Ol. Development of the composition and technology of tablets based on the phytoextract of aspen bark. Extended abstract of Candidate's thesis. Lviv: Danylo Halytsky Lviv National Medical University; 2013. Ukrainian.

22. Yuryeva O.O. Development of the composition and technology of the combined tablet medication antihypertensive action. Extended abstract of Candidate's thesis. Lviv: Danylo Halytsky Lviv National Medical University; 2019. Ukrainian.

23. Butkevych TA, Syatynya ML, Popovych VP. [Study of the excipients influence on pharmaco-technological properties of flammulina velutipes biomass dry powder tablets]. Farmatsevt chasop. 2017;3: 47-51. DOI: 10.11603/2312-0967.2017.3.8121. Ukrainian.

24. Khromylova OV. [The study of the excipients influence on pharmaco-technological characteristics of I-arginine with thiotriazolin tablets]. Farmatsevt chasop. 2018;4: 35-41. DOI: 10.11603/23120967.2018.4.9704. Ukrainian.

25. Kukhtenko OS. Methodological, technological and biopharmaceutical aspects of complex extracts and medicines on their basis development. Extended abstract of Candidate's thesis. Zaporizhzhia: Zaporizhzhia State Medical University; 2019. Ukrainian.

26. Beley NM. Development of composition, technology and research of tabulated drugs containing calcium and lecithin. Extended abstract of Candidate's thesis. Lviv: Danylo Halytsky Lviv National Medical University; 2009. Ukrainian.

27. Vasenda MM. Development of composition, technology and research of tablets based on a magnesium asparaginate. Extended abstract of Candidate's thesis. Lviv: Danylo Halytsky Lviv National Medical University; 2010. Ukrainian.

28. Demchuk MB. Development of composition, techno- logy and research of tablets famotidine with thiotriazoline. Extended abstract of Candidate's thesis. Lviv: Danylo Halytsky Lviv National Medical University; 2011. Ukrainian.

29. Denys Al. Development of composition, technology and research of tablets based on the extract of chinese poplar leaf. Extended abstract of Candidate's thesis. Lviv: Danylo Halytsky Lviv National Medical University; 2012. Ukrainian.

30. Kucherenko LI. Development of technology and standardization of tableted drugs on the basis of 1,2,4-triazole derivatives. Extended abstract of Candidate's thesis. Kharkiv: National Pharmaceutical University; 2010. Ukrainian.

31. Tryhubchak OV. Development of composition and technology of tablets which contain acid acetylsalicylic in combination with thiotriazoline. Extended abstract of Candidate's thesis. Lviv: Danylo Halytsky Lviv National Medical University; 2010. Ukrainian.

32. Barchuk OZ. Development of the composition, technology and methods of standardization of tablets on the basis of phytoextracts of bilberry leaves and goat's rue herb. Extended abstract of Candidate's thesis. Lviv: Danylo Halytsky Lviv National Medical University; 2018. Ukrainian.

33. Logoyda LS. Development and standardization of sedative pharmacological agent with extracts of valerian, lemon balm and glycine in tablets. Extended abstract of Candidate's thesis. Kharkov: National University of Pharmacy; 2013. Ukrainian.

34. Parnyuk NV. Development of technology and standardization of tablets "Hypertril". Extended abstract of Candidate's thesis. Kharkiv: National University of Pharmacy; 2016. Ukrainian.

35. Darzuli NP. Development of composition, technology and research of tablet formulations of Pyrola rotundifolia extract. Extended abstract of Candidate's thesis. Lviv: Danylo Halytsky Lviv National Medical University; 2019. Ukrainian.

36. Shoshmina OV, Gureyeva SN, Vronska LV. [Study on the influence of excipients on pharmacotechnological properties of tablet cores of dexketoprofen]. Farmatsev zhurnal. 2019;1: 53-63. DOI: 10.32352/03673057.1.19.05. Ukrainian.

\section{Відомості про авторів}

Грошовий т. А. - д. фрармац. наук, профресор, завідувач кафредри управління та економіки фрармації з технологією ліків, Тернопільський національний медичний університет імені І. Я. Горбачевського МОЗ України, Тернопіль, Україна. E-mail: grochovuy@ukr.net, ORCID 0000-0002-6427-2158.

Демчук М. Б. - канд. фрармац. наук, доцент кафредри управління та економіки фрармації з технологією ліків, Тернопільський національний медичний університет імені І. Я. Горбачевського МОЗ України, Тернопіль, Україна. E-mail: pavljukm@tdmu.edu.ua, ORCID 0000-0002-9105-2302.

Белей Н. М. - канд. фрармац. наук, доцент кафедри управління та економіки фрармації з технологією ліків, Тернопільський національний медичний університет імені І. Я. Горбачевського МОЗ України, Тернопіль, Україна. E-mail: beley@tdmu.edu.ua, ORCID 0000-0002-3682-2829.

Найда Ю. В. - аспірант кафедри управління та економіки фрармації з технологією ліків, Тернопільський національний медичний університет імені І. Я. Горбачевського МОЗ України, старший інженер технологічної лабораторії центральної лабораторії фрармацевтичної розробки ПАТ «Фармак», Київ, Україна. E-mail: y.nayda@farmak.ua.

ISSN 2312-0967. Pharmaceutical review. 2020. № 2 
Павлюк Б. В. - аспірант кафедри управління та економіки фрармації з технологією ліків, Тернопільський національний медичний університет імені І. Я. Горбачевського МОЗ України, Тернопіль, Україна. E-mail: bohdana.vons@gmail.com, ORCID 0000-0003-1276-0114.

Information about the authors

Hroshovyi T. A. - DS (Pharmacy), Professor, Head of the Department of Pharmacy Management, Economics and Technology, I. Horbachevsky Ternopil National Medical University, Ternopil, Ukraine. E-mail: grochovuy@ukr.net, ORCID 00000002-6427-2158.

Demchuk M. B. - PhD (Pharmacy), Associate Professor of the Department of Pharmacy Management, Economics and Technology, I. Horbachevsky Ternopil National Medical University, Ternopil, Ukraine. E-mail: pavljukm@tdmu.edu.ua, ORCID 0000-0002-9105-2302.

Beley N.M. - PhD (Pharmacy), Associate Professor of the Department of Pharmacy Management, Economics and Technology, I. Horbachevsky Ternopil National Medical University, Ternopil, Ukraine. E-mail: beley@tdmu.edu.ua, ORCID 00000002-3682-2829.

Nayda Yu.V. - PhD student of the Pharmacy Management, Economics and Technology Department, I. Horbachevsky Ternopil National Medical University, Senior engineer of the Technological Laboratory of the Central Laboratory of Pharmaceutical Development at PJSC "Farmak", Kyiv, Ukraine E-mail: y.naida@farmak.ua.

Pavliuk B. V. - PhD student of the Department of Pharmacy Management, Economics and Technology, I. Horbachevsky Ternopil National Medical University, Ternopil, Ukraine. E-mail: bohdana.vons@gmail.com, ORCID 0000-0003-1276-0114. 